\title{
Implementasi Pendekatan Realistic Mathematic Education (RME) terhadap Hasil Belajar Penyajian Datadi Sekolah Dasar
}

\author{
Tika Yuanda Putri ${ }^{1}$, Yetti Ariani ${ }^{2}$ \\ Pendidikan Guru Sekolah Dasar, Universitas Negeri Padang, Indonesia \\ Email : 1)tikayuanda18@gmail.com ${ }^{2}$ arianiyetti@gmail.com
}

\begin{abstract}
Abstrak
Penelitian ini bertujuan untuk mendeskripsikan Pendekatan Realistic Mathematic Education (RME) terhadap hasil belajar pada materi penyajian data di Kelas IV Sekolah Dasar. Penelitian ini menggunakan metode studi literatur (Library Research). Sumber data sekunderyang terdapat di dalam artikel atau jurnal (tercetak dan/atau non-cetak) berkenaan dengan Pendekatan Realistic Mathematics Education (RME) Terhadap Hasil Belajar Penyajian Data di Sekolah Dasar. Hasil penelitian berupa analisis atau review 25 artikel yang relevan dengan masalah yang ada pada studi literatur ini. Dari hasil penelitian 25 artikel yang relevan menunjukkan bahwa hasil uji hipotesis menggunakan uji $t(\mathrm{t}$ hitung $>t$ tabel) sehingga Ho ditolak dan Ha diterima. Dengan demikian, dapat diinterpretasikan bahwa terdapat hasil belajar matematika yang signifikan pada materi penyajian data antara kelompok siswa yang mengikuti pembelajaran dengan pendekatan Realistic Mathematic Education (RME) dengan kelompok siswa yang mengikuti pembelajaran dengan pendekatan pembelajaran konvensional pada siswa kelas IV Sekolah Dasar pada materi penyajian data.
\end{abstract}

Kata Kunci: Pendekatan Realistic Mathematic Education (RME), hasil belajar, Materi penyajian data di Kelas IV Sekolah Dasar

\section{Abstract}

This study aims to describe the of the Realistic Mathematic Education (RME) approach to learning outcomes in data presentation material in Class IV Elementary Schools. This research uses the method of literature study (Library Research). The secondary data sources are in the form of books and primary or original scientific reports contained in articles or journals (printed and / or non-printed) regarding the Realistic Mathematics Education (RME) Approach to Learning Outcomes in Primary Schools. The results of the research are in the form of analysis or review of 25 articles that are relevant to the problems in this literature study. From the research results, 25 relevant articles show that (t count> t table) so that $\mathrm{HO}$ is rejected and $\mathrm{H} 1$ is accepted. Thus, it can be interpreted that there are significant mathematics learning outcomes in the data presentation material between groups of students who take learning with the Realistic Mathematic Education (RME) approach and groups of students who take learning with conventional learning approaches in grade IV elementary school students.

Keywords:Realistic Mathematic Education (RME), learning outcomes, data presentation material in Class IV Elementary Schools

\section{PENDAHULUAN}

Matematika merupakan salah satu pelajaran yang diajarkan pada setiap jenjang pendidikan mulai dari tingkat dasar sampai perguruan tinggi sesuai dengan yang dikemukakan oleh Zainil, Helsa, dan Yanti (2018) mathematics is one the diciplines studied in educational institutions and offered to students from the primary school level up to the highter level. Hal tersebut dikarenakan pembelajaran matematika disekolah dasar memiliki tujuan yang berguna dalam kehidupan sehari-hari.Pemerintah menyatakan bahwa pembelajaran matematika disekolah dasar memiliki tujuan yaitu agar siswa memiliki 
kemampuan dalam memahami konsep matematika, menggunakan penalaran dalam matematika, memecahkan masalah, mengkomunikasikan masalah, dan memiliki sikap menghargai dalam Kenedi (2017). Pembelajaran matematika dalam pelaksanaannya harus berdasarkan pada tujuan pembelajaran matematika. Untuk mencapai tujuan pembelajaran yang diharapkan maka pembelajaran matematika menerapkan pendekatan yang dapat merangsang minat peserta didik dSelain dari permasalahan diatas peneliti juga menemukan bahwasanya dalam proses pembelajaran pendidik hanya menggunakan metode drill, dimana pendidik menjelaskan rumus dan konsep selepas itu dilanjutkan dengan peserta didik mengerjakan soal-soal. Hal ini juga dinyatakan oleh Nurayana (2016) Pendidik tidak memberikan kesempatan kepada peserta didik untuk membangun pemahaman mereka sendiri sehingga peserta didik menjadi pelajar pasif dan tidak berpartisipasi dalam proses pembelajaran. Peserta didik tidak bisa memahami pentingnya proses pembelajaran dan hanya hafal rumus tanpa memahami mekanismenya. Situasi ini menyebabkan rendahnya hasil belajar dalam matematika di kalangan peserta didik. Hal lain yang peneliti temukan ialah dari beberapa permasalahan yang muncul diatas membuat hasil belajar matematika cenderung rendah dan nilai rat-rata yang dicapai oleh siswa kurang dari KKM (Kriteria Ketuntasan Minimum.

Cara untuk mengatasi masalah diatas adalah dengan cara pembaharuan pada pendekatan pembelajaran. Pendekatan pembelajaran yang dianggap sesuai dalam pembelajaran matematika di Sekolah Dasar adalah Pendekatan Realistic Mathematics Education (RME). Pendekatan Realistic Mathematics Education (RME) adalah sebuah pendekatan belajar matematika yang menempatkan permasalahan matematika dalam kehidupan sehari-hari sehingga mempermudah siswa menerima materi dan memberikan pengalaman mereka sendiri. Dengan menggunakan Pendekatan Realistic Mathematics Education (RME) proses pembelajaran akan menjadi lebih bermakna bagi siswa karena siswa akan lebih aktif dan kreatif dalam menyelesaikan sebuah permasalahan yang diberikan sehingga berpotensi meningkatkan hasil belajar siswa. Sejalan dengan pendapat Wijaya (2012:20) menegaskan bahwa "suatu pengetahuan akan menjadi lebih bermakna bagi siswa jika proses pembelajaran dilaksanakan dalam suatu konteks atau pembelajaran menggunakan permasalahan realistik".

Pendekatan Realistic Mathematics Education (RME) ini memiliki empat tahap sebagaimana menurut Hadi (2005:37) yaitu 1) Tahap pendahuluan; 2) Tahap pengembangan model simbolik (matematisasi dan refleksi); 3) Tahap penjelasan (abstraksi dan formalisasi); 4) Tahap penutup (matematisasi dalam aplikasi). Pendekatan Realistic Mathematics Education (RME) mempunyai kelebihan yakni menurut Ariani (2018:18) ada tujuh kelebihan Pendekatan Realistic Mathematics Education (RME) yaitu, 1) pembelajaran menjadi menyenangkan; 2) memahami materi secara baik; 3) lebih kretif; 4)memberikan pengertian jelas kepada siswa bahwa mempelajari matematika melalui proses; 5)memberikan pengertian jelas kepada siswa tentang keterkaitan matematika dengan kehidupan sehari-hari; 6) adanya keterkaitan dalam materi pembelajaran dengan kehidupan sehari-hari; 7)adanya kebermaknaan dalam proses pembelajaran.

Dalam pembelajaran matematika di kelas IV terdapat berbagai materi pembelajaran matematika dan salah satunya materi mengenai penyajian data yang terdapat pada KD. 3.11 Menjelaskan data diri peserta didik dan lingkungannya yang disajikan dalam bentuk diagram batang, dan KD 4.11 Mengumpulkan data diri peserta didik dan lingkungannya yang disajikan dalam bentuk diagram batang. Dengan menggunakan Pendekatan Realistic Mathematics Education (RME) pada materi penyajian data, diharapkan dapat meningkatkan pengetahuan dan pengaruh baik terhadap hasil belajar peserta didik di Sekolah Dasar.

Berdasarkan uraian yang telah dipaparkan diharapkan siswa dapat mencapai hasil belajar yang memuaskan dan semuanya dapat mencapai KKM, maka penulis tertarik untuk menulis studi literatur dengan judul "Implementasi Pendekatan Realistic Mathematics Education (RME) Terhadap Hasil Belajar Penyajian Data Di Sekolah Dasar". 


\section{METODE PENELITIAN}

Jenis penelitian yang digunakan dalam penulisan ini adalah studi literatur (Library Research). Menurut Sugiyono (2018) metode studi literatur (Library Research) merupakan metode yang digunakan penulis melalui berbagai kajian kepustakaan dalam memperkuat analisis yang didukung dari berbagai sumber yang memiliki kedalaman teori. Menurut Narbuko (2015) Langkah-langkah dari studi literatur (Library Research) yaitu : (1) Penentuan ide tugas akhir untuk membuat studi literatur, (2) Penentuan judul tugas akhir, (3) Mencari Literatur dengan Google Schoolar, atau situs yang berkaitan dengan artikel yang sesuai dengan studi literatur. (4) Persiapan data - data yang diperlukan untuk kelengkapan studi literatur. (5) Penyusunan hasil (6) Analisa hasil dengan studi literatur yang diambil (7) Penentuan Kesimpulan.

Data yang digunakan dalam penelitian ini adalah data sekunder. Menurut Hermawan (2019) data sekunder merupakan data yang diperoleh bukan dari pengamatan langsung. Akan tetapi data tersebut diperoleh dari hasil penelitian yang telah dilakukan oleh penelitipeneliti terdahulu. Metode pengumpulan data yang digunakan dalam penelitian ini adalah metode literatur. Menurut Mizaqon (2017) salah satu teknik pengumpulan data yang bisa diterapkan dalam penelitian kepustakaan adalah teknik dokumentasi, yaitu dengan cara mencari data mengenai hal-hal atau variabel-variabel yang berupa catatan, buku, artikel, makalah atau jurnal dan sebagainya. Instrumen penelitian yang digunakan pada penelitian studi literature ini adalah daftar check-list klasifikasi bahan penelitian berdasarkan dengan focus kajian, skema/peta penulisan dan format catatan penelitian.

Teknik analisis data yang digunakan dalam penelitian ini adalah metode analisisisi (Content Analysis). Dalam analisis ini dilakukan proses memilih, membandingkan, menggabungkan dan memilah berbagai pengertian hingga ditemukan data yang relevan.

\section{HASIL DAN PEMBAHASAN}

Hasil Analisis review jurnal dalam implementasi Pendekatan Realistic Mathematics Eduaction (RME) di Sekolah Dasar pada materi penyajian data di kelas IV. Dalam review jurnal yang peneliti dapat sebanyak 25 jurnal, jurnal yang didapat ialah jurnal yang menggunakan pendekatan kuantitatif dengan desain desain penelitian One-Group PretestPosttest Design. Menurut Devi, C., Utari, T. S. G., \& Nurkanti, M., (2018), One-Group Pretest-Posttest Design yang mencakup satu kelompok yang pada saat tahap pretest dilakukan observasi subjek penelitian yang dilanjutkan dengan memberikan perlakuan (treatment) dan pemberian soal posttest di akhir proses pembelajaran. Hasil perlakuan yang diperoleh lebih akurat karena ada proses membandingkan dengan keadaan sebelum dan setelah diberi perlakuan (treatment) sehingga dapat diketahui pengaruhnya. Hasil yang peneliti temukan dapat dilihat dalam tabel hasil review jurnal yang memiliki pengaruh sangat tinggi dalam hasil belajar penyajian data di kelas IV Sekolah Dasar.

Berikut ini hasil temuan peneliti terkait implementasi Pendekatan Realistic Mathematics Eduaction (RME) pada materi penyajian data di kelas IVdi Sekolah Dasar. Berdasarkan hasil analisis peneliti dalam 25 jurnal terkait penerapan Pendekatan Realistic Mathematics Education (RME) pada materi penyajian data didapat persamaan antara 25 jurnal tersebut ialah : 1) Proses pembelajaran mengkaitkan dengan kehidupan sehari-hari, 2) Keberhasilan proses belajar dianggap penting dengan kebermaknaan proses belajar itu sendiri dengan menyesuaikan materi pembelajaran dengan pengalaman siswa, dan sesuai taraf pengetahuan siswa, 3) Tahap yang digunakan dalam penerapan penerapan 
Pendekatan Realistic Mathematics Education (RME) pada materi penyajian data terdiri dari empat tahap yaitu pendahuluan, menggunakan model simbolik, penjelasan , serta penutup, 4) Didapatkan temuan bahwasanya ke 25 jurnal yang dipaparkan menggunakan karakteristik yang ada dalam pendekatan RME,5)Hasil belajar yang dilihat dalam jurnal sebanyak 25 tersebut ialah hanya pada ranah pengetahuan dengan cara memberikan tes dalam bentuk pretest dan posttest, 6) Didapat hasil ketuntasan belajar siswa yang lebih meningkat dibandingkan dengan menggunakan pendekatan konvensional, 7)Didapat data uji hipotesis yang menyatakan bahwa benar adanya pengaruh penerapan Pendekatan Realistic Mathematics Education (RME) pada materi penyajian data dibuktikan dengan uji hipotesis dimana dalam 25 jurnal tersebut t hitung lebih besar dibanding $t$ tabel.

Bukan hanya mendapatkan persamaan dari hasil analisis 25 jurnal tersebut, tetapi peneliti juga menemukan perbedaan yaitu 1) ditemukan perbedaan peningkatan hasil posttest dari tiap-tiap jurnal, 2) ditemukan perbedaan ketuntasan hasil belajar dari tiap-tiap jurnal, dimana sebanyak 8 jurnal mencapai ketuntasan tertinggi yaitu $95 \%$ menggunakan Pendekatan Realistic Mathematics Education (RME) dalam materi penyajian data dibanding dengan menggunakan pendekatan konvensional yang digunakan dalam materi penyajian data 3) ditemukan perbedaan dari hasil uji hipotesis dari setiap jurnal meskipun menyatakan kesimpulan hipotesis bahwa benar pada penerapan menggunakan Pendekatan Realistic Mathematics Education (RME) benar memiliki pengaruh dalam meningkatkan hasil belajar siswa dalam materi penyajian data.Sesuai dengan analisis peneliti dalam 25 jurnal terkait implementasi Pendekatan Realistic Mathematics Education (RME) dalam materi penyajian data di kelas IV Sekolah Dasar ditemukan adanya 8 jurnal yang memiliki pengaruh sangat baik dan signifikan dalam meningkatkan hasil belajar dalam materi penyajian data dibuktikan dengan peningkatan hasil belajar mencapai taraf $95 \%$.

\section{SIMPULAN}

Berdasarkan hasil penelitian studi literatur (Library Reseach) diatas dapat disimpulkan bahwa penerapan Pendekatan Realistic Mathematics Eduaction (RME) dapat membantu guru dalam meningkatkan hasil belajar siswa pada materi penyajian data. Hal ini dibuktikan dengan data dari tabel hasil analisis penerapan Pendekatan Realistic Mathematics Eduaction (RME) yang mengungkapkan bahwa adanya kenaikan hasil belajar siswa yang signifikan. Selain meningkatkan hasil belajar siswa, Pendekatan Realistic Mathematics Eduaction (RME) juga mampu meningkatkan keaktifan siswa, rasa percaya diri siswa, dan kemampuan berfikir kritis siswa dalam menyelesaikan suatu permasalahan secara mandiri.

\section{DAFTAR PUSTAKA}

Arintasari, I. Z., Rahmawati, I., \& Sukamto, S. (2019). Pengaruh Pendekatan Realistic Mathematics Education (RME) Terhadap Hasil Belajar Matematika Siswa Kelas IV SD Pada Materi Penyajian Data. Universitas PGRI Semarang : International Journal of Elementary Education, 3(4), 366-372.

Ariani, Yetti.(2015).Pembelajaran dengan Pendekatan Realistik untuk Pemahaman Konsep Statistika Siswa Kelas IV SDN 20 Kubang Payakumbuh.Tesis Tidak diterbitkan. Malang PPS Pendidikan Matematika SD Universitas Negeri Malang.

Ariani, Yetti. (2018). Penerapan Pendekatan Realistics Mathematics Education (RME) untuk Meningkatkan Hasil Belajar Penyajian Data Siswa Kelas IV Sekolah Dasar. Jurnal Cendekia: Jurnal Pendidikan Matematika, 2(1), 125-133.

Artika, R. V., Sudrajat, R., \& Wijayanti, A. (2019). Pengaruh Pendekatan Realistic Mathematics Education (RME) Terhadap Hasil Belajar Matematika Siswa Kelas IV 
SD Pada Materi Penyajian Data. Semarang : Jurnal Ilmiah Sekolah Dasar, 3(4), 481488.

Ary Partini., A. A. Gede Agung., \& I Nym Arcana. (2013). Pengaruh Pendekatan Realistic Mathematic Education (RME) Terhadap Hasil Belajar Matematika Siswa Kelas IV SD Pada Materi Penyajian Data di Desa Pemaron. Singaraja : Universitas Pendidikan Ganesha

Atikah, N., Karjiyati, V., \& Noperman, F. (2020). Pengaruh Pendekatan Realistic Mathematics Education (RME) Terhadap Hasil Belajar Matematika Siswa Kelas IV SD Pada Materi Penyajian Data di Kota Bengkulu. JURIDIKDAS: Jurnal Riset Pendidikan Dasar, 3(1), 25-32.

Azizah, A., Aeni, A. N., \& Maulana, M. (2017). Pengaruh Pendekatan Realistic Mathematics Education (RME) Terhadap Hasil Belajar Matematika Siswa Kelas IV SD Pada Materi Penyajian Data. Sumedang : Jurnal Pena IImiah, 2(1), 861-870.

Bely, L. N., Bahri, S., \& Mustari, M. (2019). Model Pembelajaran Advance Organizer: Dampak Terhadap Hasil Belajar Kognitif Peserta Didik. Indonesian Journal of Science and Mathematics Education, 2(2), 150-161.

Claudia, S., Suryana, Y., \& Pranata, O. H.(2020). Pengaruh Pendekatan Realistic Mathematics Education (RME) Terhadap Hasil Belajar Matematika Siswa Kelas IV SD Pada Materi Penyajian Data.Universitas Pendidikan Indonesia Kampus Tasikmalaya: Jurnal IImiah Pendidikan Guru Sekolah Dasar, 7(2), 210-221.

Fariz, I. N., \& Isrok'atun, I.(2016). Pengaruh Pendekatan Realistic Mathematics Education (RME) Terhadap Hasil Belajar Matematika Siswa Kelas IV SD Pada Materi Penyajian Data. Semarang : Jurnal Pena IImiah, 2(1), 751-760.

Firmansyah, R., Handoko, S., \& Gunawan, I. (2019). Penerapan Pendekatan Realistics Mathematics Education (RME) untuk Meningkatkan Hasil Belajar Penyajian Data Siswa Kelas IV Sekolah Dasar.Universitas Lalang Buana : EDUCARE, 42-49.

Fitriani, P., Permana, R., \& Nugraha, M. F. (2019). Pengaruh Pendekatan Realistic Mathematics Education (RME) Terhadap Hasil Belajar Matematika Siswa Kelas IV SD Pada Materi Penyajian Data. Semarang : Indonesian Journal of Primary Education, 3(2), 73-82

Hadi, Sutarto. (2005). Pendidikan Matematika Realistik. Banjarmasin: Tulip.

Hamalik, O. (2014). Teacher Education Based on Competency Approach. Jakarta: PT Bumi Aksara.

Hobri. (2009). Model-Model Pembelajaran Inovatif. Jember: Center for Society Studies.

Kenedi, Ary Kiswanto dan Yullys Helsa. (2017). Literasi Matematis Dalam Pembelajaran Berbasis Masalah. UNP Press: Padang.

Luthfiani, A., Irianto, S., \& Andriani, A. (2019). Pengaruh Pendekatan Realistic Mathematics Education (RME) terhadap Hasil Belajar pada Materi Penyajian Data di Kelas IV. Universitas Purwarketo : JTAM (Jurnal Teori dan Aplikasi Matematika), 3(2), 80-86.

Narayana, I. M. E., Wiarta, I. W., \& Sujana, I. W. (2013).Pengaruh Pendekatan Realistic Mathematics Education (RME) terhadap Hasil Belajar pada Materi Penyajian Data di Kelas IV Gugus I Gusti Ngurah Rai.Singaraja Universitas Ganesha: MIMBAR PGSD Undiksha, 1(1).

Pramita, P. D.(2018). Pengaruh Pendekatan Realistic Mathematics Education (RME) terhadap Hasil Belajar pada Materi Penyajian Data di Kelas IV SD N Kuncilan.Semarang. JS (JURNAL SEKOLAH), 2(4), 276-280.

Rismawati, R., \& Handayani, H. (2018). Pengaruh Pendekatan Realistic Mathematics Education (RME) terhadap Hasil Belajar pada Materi Penyajian Data di Kelas IV. 
Banten: JURNAL SILOGISME Kajian IImu Matematika dan Pembelajarannya, 3(3), 121-127.

Rizqi, M. (2019). Pengaruh Pendekatan Realistic Mathematics Education (RME) terhadap Hasil Belajar pada Materi Penyajian Data di Kelas IV. Malang. In Prosiding Seminar Nasional PGSD UNIKAMA (Vol. 3, No. 1, pp. 524-534).

Reinita, T. Taufina, \& L. Yusnita. (2018). Peningkatan Hasil Belajar PKN Dengan Model Everyone is Teacher Here di Kelas V SD. Padang : Jurnal Inovasi Pembelajaran Sekolah Dasar 6 (2),9-35

Reinita, Z. Abidin, \& O. Adela. (2018). Pengaruh Model PBL Terhadap Hasil Belajar Siswa Pada Pembelajaran Pendidikan Kewarganegaraan Kelas V Sekolah Dasar. Padang: Jurnal Inovasi Pembelajaran Sekolah Dasar 6 (1),11-16

Saadah, U. J. M., \& Hasanah, S. A. (2018). Pengaruh Pendekatan Realistic Mathematics Education (RME) terhadap Hasil Belajar pada Materi Penyajian Data diKelas IV di SD IT Kaifa Bogor. Bogor : Jurnal Pendidikan Dasar, 9(1), 143-155.

Soedjadi, R. (2016). Inti Dasar-Dasar Pendidikan Matematika Realistik Indonesia.(online),(https://ejournal.unsri.ac.id/index.php/jpm/article/view/807 diakses 24 agustus 2020).

Sugiyono. (2018). Penggunaan Literatur dalam Penelitian Kualitatif. Jurnal Keperawatan Indonesia, 9(1), 32-35.

Sulianto, J., \& Prabowo, K. E. (2013). Pengaruh Pendekatan Realistic Mathematics Education (RME) terhadap Hasil Belajar pada Materi Penyajian Data di Kelas IV SDN Karangayu 02. Semarang: Malih Peddas (Majalah IImiah Pendidikan Dasar), 3(2).

Supardi U.S. (2013). Pengaruh Pendekatan Realistic Mathematic Education (RME) Terhadap Hasil Belajar Matematika Siswa Kelas IV SD Pada Materi Penyajian Data Gugus IX Banda Kali.Jakarta : FTMIPA Universitas Indraprasta PGRI.

Susanto. (2013). Belajar dan Pembelajaran. Jakarta : Rineka Cipta.

Wanelly,W., Yunisrul, Y. Y., \& Zainil M. (2018). Perbedaan Hasil Belajar Matematika Siswa Antara Model Cotextual Teaching and Learning (CTL) dengan Pendekatan Realistic Mathematic Education (RME). e- Journal Pembelajaran Inovasi, Jurnal IImiah Pendidikan Dasar, 6 (2).

Wijaya, A. (2012). Pendidikan Matematika Realistik Suatu Alternatif Pendekatan Pembelajaran Matematika. Yogyakarta: Graha IImu .

Yanto, A., Yuliati, Y., \& Anjani, T. (2020). Pengaruh Pendekatan Realistic Mathematic Education (RME) Terhadap Hasil Belajar Matematika Siswa Kelas IV SD Pada Materi Penyajian Data. Universitas Majalengka : Jurnal Elementaria Edukasia, 3(1).

Yusimarliah, E. (2015). Pengaruh Pendekatan Realistic Mathematic Education (RME) Terhadap Hasil Belajar Matematika Siswa Kelas IV SD Pada Materi Penyajian Data SD Perapat Cinaru.Bandung. JKPM (Jurnal Kajian Pendidikan Matematika), 1(1), 115.

Zainil, M., Helsa, Y., Zainil, Y., \& Yanti, W. T. (2018). Mathematics learning through pendidikan matematika realistik Indonesia (PMRI) approach and Adobe Flash CS6. Journal of Physics: Conference Series, 1088. https://doi.org/10.1088/17426596/1088/1/012095 (akses : 04 Agustus 2020)

Zulkardi, Z., Putri, R. I. I., \& Wijaya, A. (2020). Pengaruh Pendekatan Realistic Mathematic Education (RME) Terhadap Hasil Belajar Matematika Siswa Kelas IV SD Pada Materi Penyajian Data SD (pp. 325-340). Springer, Cham 
Tabel 1. Hasil Review Jurnal yang memiliki pengaruh sangat tinggi dalam hasil penyajian data menggunakan Pendekatan RME di kelas IV SD

\begin{tabular}{|c|c|c|c|c|c|c|c|c|c|}
\hline \multirow[t]{2}{*}{ No } & \multirow[t]{2}{*}{ Nama Penulis Tahun } & \multirow[t]{2}{*}{ Judul } & & \multicolumn{2}{|c|}{ Hasil Penelitian } & \multicolumn{2}{|l|}{$\begin{array}{l}\text { Hasil Penelitian } \\
\text { Ketuntasan Siswa } \\
\text { KKM }(\geq 75)\end{array}$} & \multicolumn{2}{|c|}{$\begin{array}{c}\text { Hasil Uji hipotesis } \\
\text { Uji t }(\alpha=0,05)\end{array}$} \\
\hline & & & & Pretest & Post & $\begin{array}{ll}\text { st } & \text { Kelas } \\
& \text { Kontrol }\end{array}$ & Kelas Eksperimen & $t_{\text {hitung }}$ & $t_{\text {tabel }}$ \\
\hline 1. & $\begin{array}{l}\text { Meiriyani, } \\
\text { Kristiantari, M. M., } \\
\text { Wiarta, I. W. }\end{array}$ & 2014 & $\begin{array}{l}\text { Pengaruh Pendekatan Realistic } \\
\text { Mathematics Education (RME) } \\
\text { Terhadap Hasil Belajar Pada } \\
\text { Materi Penyajian Data Di Kelas } \\
\text { IV Gugus VI Moch. Hatta Panjer } \\
\text { Denpasar Selatan Tahun Ajaran } \\
\text { 2013/2014. }\end{array}$ & 41,98 & 73,92 & $\begin{array}{l}\text { Siswa yang tuntas } \\
\text { sebanyak } 7 \text { orang dari } \\
21 \text { orang siswa. } \\
\text { Dengan persentase } \\
\text { ketuntasan } 33 \%\end{array}$ & $\begin{array}{l}\text { Siswa yang tuntas } \\
\text { sebanyak } 20 \text { orang dari } \\
21 \text { orang siswa. Dengan } \\
\text { persentase ketuntasan } \\
95 \%\end{array}$ & 4,26 & 2,15 \\
\hline 2. & Yusimarliah, E & 2015 & $\begin{array}{l}\text { Pengaruh Pendekatan Realistic } \\
\text { Mathematic Education (RME) } \\
\text { Terhadap Hasil Belajar } \\
\text { Matematika Siswa Kelas IV SD } \\
\text { Pada Materi Penyajian Data SD } \\
\text { Perapat Cinaru }\end{array}$ & 50,03 & 69,49 & $\begin{array}{l}\text { Siswa yang tuntas } \\
\text { sebanyak } 12 \text { orang dari } \\
21 \text { orang siswa. } \\
\text { Dengan persentase } \\
\text { ketuntasan } 57,10 \%\end{array}$ & $\begin{array}{l}\text { Siswa yang tuntas } \\
\text { sebanyak } 20 \text { orang dari } \\
21 \text { orang siswa. Dengan } \\
\text { persentase ketuntasan } \\
95 \%\end{array}$ & 4,306 & 2,641 \\
\hline 3. & $\begin{array}{l}\text { Sa'diah, } \\
\text { U. J. M., \& Hasanah, } \\
\text { S. A }\end{array}$ & 2018 & $\begin{array}{l}\text { Pengaruh Pendekatan Realistic } \\
\text { Mathematics Education (RME) } \\
\text { terhadap Hasil Belajar pada } \\
\text { Materi Penyajian Data di Kelas } \\
\text { IV Di SD IT Kaifa Bogor }\end{array}$ & 64,81 & 86,06 & $\begin{array}{l}\text { Siswa yang tuntas } \\
\text { sebanyak } 15 \text { siswa dari } \\
41 \text { siswa. } \\
\text { Dengan persentase } \\
\text { ketuntasan } 36,5 \%\end{array}$ & $\begin{array}{l}\text { Siswa yang tuntas } \\
\text { sebanyak } 39 \text { siswa dari } \\
41 \text { siswa. } \\
\text { Dengan persentase } \\
\text { ketuntasan } 95,1 \%\end{array}$ & 5,15 & 2,56 \\
\hline
\end{tabular}




\begin{tabular}{|c|c|c|c|c|c|c|c|c|c|}
\hline 4. & $\begin{array}{lrr}\text { Arintasari, } & \text { I. } & \text { Z., } \\
\text { Rahmawati, } & \text { I., } & \text { \& } \\
\text { Sukamto, S } & & \end{array}$ & 2019 & $\begin{array}{l}\text { Pengaruh Pendekatan Realistic } \\
\text { Mathematics Education (RME) } \\
\text { Terhadap Hasil Belajar } \\
\text { Matematika Siswa Kelas IV SD } \\
\text { Pada Materi Penyajian Data }\end{array}$ & 67,89 & 80,21 & $\begin{array}{l}\text { Siswa yang tuntas } \\
\text { sebanyak } 15 \text { orang dari } \\
20 \text { orang siswa . } \\
\text { Dengan persentase } \\
\text { ketuntasan } 75 \%\end{array}$ & $\begin{array}{l}\text { Siswa yang tuntas } \\
\text { sebanyak } 19 \text { orang dari } \\
20 \text { orang siswa. Dengan } \\
\text { persentase ketuntasan } \\
95 \%\end{array}$ & 4,15 & 1,67 \\
\hline 5. & $\begin{array}{l}\text { Fitriani, P., Permana, } \\
\text { R., \& Nugraha, M. F. }\end{array}$ & 2019 & $\begin{array}{l}\text { Pengaruh Pendekatan Realistic } \\
\text { Mathematics Education (RME) } \\
\text { Terhadap Hasil Belajar } \\
\text { Matematika Siswa Kelas IV SD } \\
\text { Pada Materi Penyajian Data }\end{array}$ & 40,78 & 85,15 & $\begin{array}{l}\text { Siswa yang tuntas } \\
\text { sebanyak } 4 \text { orang dari } \\
21 \text { orang siswa. } \\
\text { Dengan persentase } \\
\text { ketuntasan } 19 \%\end{array}$ & $\begin{array}{l}\text { Siswa yang tuntas } \\
\text { sebanyak } 20 \text { orang dari } \\
21 \text { orang siswa. Dengan } \\
\text { persentase ketuntasan } \\
95 \%\end{array}$ & 2,287 & 1,008 \\
\hline 6. & $\begin{array}{l}\text { Luthfiani, A., Irianto, } \\
\text { S., \& Andriani, A. }\end{array}$ & 2019 & $\begin{array}{l}\text { Pengaruh Pendekatan Realistic } \\
\text { Mathematics Education (RME) } \\
\text { terhadap Hasil Belajar pada } \\
\text { Materi Penyajian Data di Kelas } \\
\text { IV }\end{array}$ & 50,15 & 79,01 & $\begin{array}{l}\text { Siswa yang tuntas } \\
\text { sebanyak } 5 \text { orang dari } \\
21 \text { orang siswa. } \\
\text { Dengan persentase } \\
\text { ketuntasan } 23,8 \%\end{array}$ & $\begin{array}{l}\text { Siswa yang tuntas } \\
\text { sebanyak } 20 \text { orang dari } \\
21 \text { orang siswa. Dengan } \\
\text { persentase ketuntasan } \\
95 \%\end{array}$ & 2,14 & 1,23 \\
\hline 7. & $\begin{array}{l}\text { Rosyada, T. A., Sari, } \\
\text { Y., \& Cahyaningtyas, } \\
\text { A. P. }\end{array}$ & 2019 & $\begin{array}{l}\text { Pengaruh Pendekatan Realistic } \\
\text { Mathematics Education (RME) } \\
\text { Terhadap Hasil Belajar } \\
\text { Matematika Siswa Kelas IV SD } \\
\text { Pada Materi Penyajian Data } \\
\text { Negeri Prampelan }\end{array}$ & 60,06 & 70,03 & $\begin{array}{l}\text { Siswa yang tuntas } \\
\text { sebanyak } 9 \text { orang dari } \\
21 \text { orang siswa. } \\
\text { Dengan persentase } \\
\text { ketuntasan } 42,8 \%\end{array}$ & $\begin{array}{l}\text { Siswa yang tuntas } \\
\text { sebanyak } 19 \text { orang dari } \\
20 \text { orang siswa . Dengan } \\
\text { persentase ketuntasan } \\
95 \%\end{array}$ & 2,091 & 2,049 \\
\hline 8. & $\begin{array}{lr}\text { Saraseila, } & \text { F., } \\
\text { Karjiyati, V., } & \text { \& } \\
\text { Agusdianita, N. } & \end{array}$ & 2020 & $\begin{array}{l}\text { Pengaruh Pendekatan Realistic } \\
\text { Mathematics Education (RME) } \\
\text { terhadap Hasil Belajar pada } \\
\text { Materi Penyajian Data di Kelas } \\
\text { IV GUGUS XIV KOTA } \\
\text { BENGKULU }\end{array}$ & 43,04 & 73,25 & $\begin{array}{l}\text { Siswa yang tuntas } \\
\text { sebanyak } 9 \text { orang dari } \\
24 \text { orang siswa. } \\
\text { Dengan persentase } \\
\text { ketuntasan } 37,5 \%\end{array}$ & $\begin{array}{l}\text { Siswa yang tuntas } \\
\text { sebanyak } 19 \text { orang dari } \\
20 \text { orang siswa . Dengan } \\
\text { persentase ketuntasan } \\
95 \%\end{array}$ & 4,09 & 2,07 \\
\hline
\end{tabular}

